\title{
Anthesis, the infectious process and disease progress curves for fusarium head blight in wheat
}

\author{
Erlei Melo Reis²; Cristina Boareto'; Anderson Luiz Durante Danelli1; Sandra Maria Zoldan²
}

${ }^{1}$ Universidade de Passo Fundo, Passo Fundo, RS; ${ }^{2} \mathrm{OR}$ Melhoramento de Sementes Ltda, Passo Fundo, RS.

Autor para correspondência: Erlei Melo Reis (erleireis@upf.br)

Data de chegada: 16/01/2015. Aceito para publicação em: 07/07/2015. \begin{abstract}
wheat. Summa Phytopathologica, v.42, n.2, p.134-139, 2016.
Fusarium head blight of wheat (Triticum aestivum), caused by the fungus Gibberella zeae, is a floral infecting disease that causes quantitative and qualitative losses to winter cereals. In Brazil, the sanitary situation of wheat has led to research in order to develop strategies for sustainable production, even under adverse weather conditions. To increase the knowledge of the relationship among the presence of anthesis, the infectious process, the disease progress and the saprophytic fungi present in wheat anthers, studies were conducted in the experimental field of University of Passo Fundo (UPF), using the cultivar Marfim, in the 2011 growing season. The
\end{abstract}

ABSTRACT

$10.1590 / 0100-5405 / 2075$

Reis, E.M.; Boareto, C.; Danelli, A.L.D.; Zoldan, S.M. Anthesis, the infectious process and disease progress curves for fusarium head blight in

disease incidence in spikes and spikelets was evaluated. The presence of exserted anthers increased the spike exposure time to the inoculum. The final incidence of fusarium head blight, in the field, was dependent on the presence of exserted anthers. The disease followed an aggregation pattern and its evolution increased with time, apparently showing growth according to secondary cycles. The fungi isolated from exserted anthers (Alternaria sp., Fusarium sp., Drechslera spp. and Epicoccum sp.) did not compete for the infection site of fusarium head blight in wheat, not interfering with the incidence of $F$. graminearum.

Keywords: Epidemiology, Fusarium graminearum, head scab, Gibberella zeae, Triticum aestivum.

\section{RESUMO}

Reis, E.M.; Boareto, C.; Danelli, A.L.D.; Zoldan, S.M. Antese, o processo infeccioso e curvas de progresso da giberela em trigo. Summa Phytopathologica, v.42, n.2, p.134-139, 2016.

A giberela do trigo (Triticum aestivum) causada pelo fungo Gibberella zeae, é uma doença de infecção floral causando danos quantitativos e qualitativos, em cereais de inverno. No Brasil, a situação sanitária do trigo tem levado a pesquisa a desenvolver estratégias para a produção sustentável, mesmo sob condições climáticas adversas. Visando a ampliar o conhecimento da relação da presença de anteras com o processo infeccioso, o progresso da doença e os fungos saprofíticos presentes nas anteras do trigo, foram conduzidos experimentos na área experimental da UPF, com o cultivar Marfim na safra 2011. Foram avaliadas a incidência da doença em espigas e em espiguetas. A presença das anteras presas aumentou o período de exposição das espigas ao inóculo. A incidência final da giberela, no campo, foi dependente da presença das anteras presas. A doença seguiu um padrão de agregação, aumentando a evolução da doença no tempo, aparentemente apresentando crescimento em função de ciclos secundários. Os fungos isolados de anteras presas (Alternaria sp., Fusarium sp., Drechslera spp. e Epicoccum sp.) não competiram pelo sítio de infecção da giberela em trigo, não interferindo na incidência de $F$. graminearum.

Palavras-chave: Epidemiologia, Fusarium graminearum, fusariose, Gibberella zeae, Triticum aestivum.

Fusarium head blight (FHB), or scab of wheat (Triticum aestivum L.), is caused by Gibberella zeae Petch, anamorph Fusarium graminearum Schwabe (1, 2, 3, and 4). The role of anthers in Fusarium infection has been reported in the literature for many decades, since initial FHB in wheat was shown to occur via anthers $(1,17,22,24$, 25, 26, and 27).

FHB of wheat is a floral infecting disease. De Vries (9) has described the flowering process of wheat in detail. The hermaphrodite wheat flower is composed of a single pistil and three stamens. During stigma fecundation, anthers are extruded from the anthecium. The number of extruded anthers can vary from zero to three, which in a few minutes are dehisced from the apical tiny filet. During extrusion, some anthers are retained between the palea and the lemma at the moment they close after fecundation and during anther exclusion. These anthers called caught, partially exserted anthers (PEA) remain trapped until wheat harvest.

Wheat susceptibility to G. zeae infection is extended from the beginning of anthesis to the ripening (still green heads). The fully exserted anthers (FEA), which remain outside, hung by the fillet, do not explain FHB infection after anthesis. The anthers that remain at the heads are those partially exserted and hence explain the long predisposing period to $G$. zeae infection.

Initial FHB infection was thought to occur via the anthers due to the presence of the stimulants betaine and choline at high concentrations $(25,26)$. However, subsequently, Engle et al. (10) reported that $F$. graminearum spore germination, as well as radial hyphal growth, was not significantly affected by choline and betaine; thus, these endogenous compounds may not be associated with $F$. graminearum infection.

FHB occurrence and mycotoxin accumulation in infected grains 
are widespread, causing yield and grain quality reduction in all wheat growing areas (27).

Severe epidemics often occur when favorable environmental conditions for fungal infection coincide with vulnerable crop growth stages (1). However, the susceptible period extends from the beginning of flowering to the grain dough stage.

Grain yield reduction due to FHB has been quantified for different wheat cultivars from 1984 to 2010 growing seasons, in Rio Grande do Sul State. The loss, average of 21 growing seasons, was $18.6 \%$, with maximum of $39.9 \%(6,11,15$, and 16$)$.

Fusarium head blight was first described by Arthur in 1891 (2), and in Brazil (RS) by Costa Netto in 1947 (8). Although it has been known for a long time, this disease has not shown an effective control measure yet.

Gibberella zeae produces two types of spores, the ascospores and the conidia, both of which are infective to wheat heads $(12,13,14,17$, and 21). The ascospores are formed within perithecia, under hot and humid environmental conditions, at temperatures between $5-35^{\circ} \mathrm{C}$; they are released due to perithecium hydration, spread by the wind (12, 24, 27 ), and deposited on susceptible organs, the anthers. The existence of primary or secondary cycles in FHB remains uncertain; however, it is important to define management strategies. Sutton $(27,28)$ reports that this disease is monocyclic since, in the initial inoculation, the ascospores come from crop residues and cause only one infection cycle. However, the question is: how does this disease grow in spike and spikelets? Andersen (1), Maloy \& Strausbaug (24), and Wiese (28) report that conidia of the fungus formed on the heads can cause secondary infections when removed by the rain. In Southern Brazil, ascospores are trapped in the air throughout the year (18).

This study was conducted to better understand the relationship between anthers and the infectious process, to plot the disease progress curve and to determine the saprophytic fungi found in partially exserted anthers of wheat.

\section{MATERIAL AND METHODS}

The study was conducted in the experimental field of University of Passo Fundo, located at latitude $28^{\circ} 15$ > S, $52^{\circ} 24^{\prime} \mathrm{W}$ and at $684 \mathrm{~m}$ above sea level, and in the Laboratory of Phytopathology - Mycology. Wheat cultivar Marfim was seeded on 07.25.2011, in four blocks of five rows spaced at $0.15 \mathrm{~m}$ and $6.0 \mathrm{~m}$ in length.

To quantify the exposed or fully exserted anthers (FEA) and caught or partially exserted anthers (PEA), 20 plants of the centerline in each plot, totaling 80 plants, were identified in the neck with a wool string. Counts began at early flowering and ended when the number of PEA was constant on two consecutive days. The evaluations were daily performed at around the same time (11 a.m.). FHB incidence was determined in 25 heads per plot, by marking with a wool string. The evaluations were daily performed, counting the number of heads showing the first infection symptoms, the white twisted awns, the discolored glumes, and the number of infected spikelets per head. Counts were done up to grain dough stage (still green heads).

Experimental design was in randomized blocks, and data underwent regression analysis, using the program CoStat.

At weekly intervals, PEA were collected, plated on Petri dishes containing potato dextrose agar (1/4PDA) and Segalin \& Reis (23) semi-selective medium and incubated in a growth chamber at $12 \mathrm{~h}$ photoperiod for seven days at $25^{\circ} \mathrm{C}$; subsequently, under a stereoscope microscope, fungi that colonized the anther were identified.

Experimental design was in randomized blocks with five plates containing nine anthers each, and means were compared according to Turkey's test at 0.01 . Experiments were repeated twice.

\section{RESULTS AND DISCUSSION}

\section{Anthesis evolution - Fully exserted anthers and partially exserted anthers.}

The main tiller of Marfim cultivar sown on $07 / 25 / 2011$ had its flowering beginning on 10/01/2011; the number of FEA was maximal on the sixth day after the first anther exposure and reached zero on the $12^{\text {th }}$ day, lasting thus for six days (Figure 1A). The difference in time between the maximum FEA exposure and the PEA was seven days. Therefore, the predisposition period to the inoculum was only one week for FEA. However, if they had been infected and dehisced, the inoculum would have been taken to the ground, not contributing to the infection. The mean PEA per spike was 2.5 and remained in the ear (Figure 1B) for a long time, receiving inoculum, which may increase the infection likelihood.
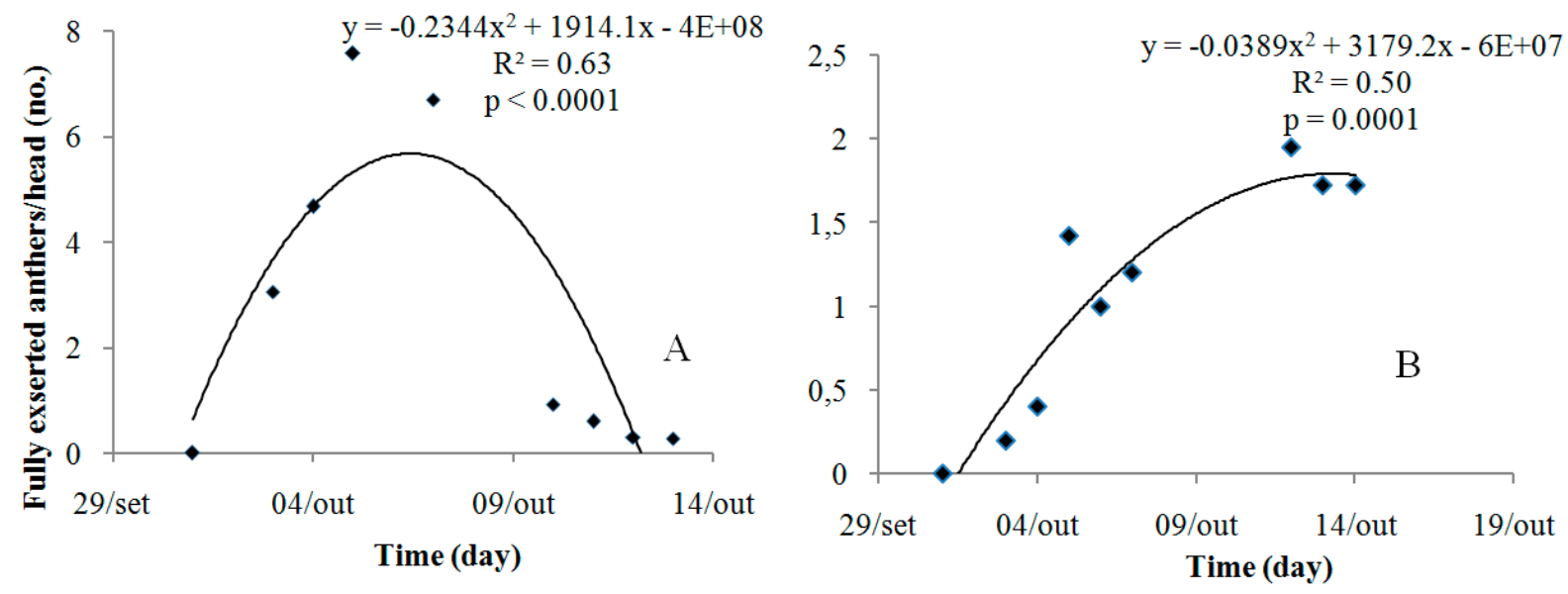

Figure 1. (A) Evolution of fully exserted anthers per head (no.) and (B) progress curve of partially exserted anthers per head (no.), wheat cultivar Marfim. 
Our data differ from those of Atanasoff (2), who reported that wheat heads show the highest susceptibility at the time of anther extrusion. Vargas (29) and Zoldan (31) reported that the days of exposure to the inoculum were restricted from the 15th to the 17th day of FEA exposure. It should also be considered that differences in anthesis duration between cultivars could account for differences in susceptibility, as described by Zoldan (31). If wetness duration necessary for infection (30) does not occur during the 12 days of anthesis duration (FEA), FHB does not occur; however, after the absence of FEA, with the fulfillment of wetting requirement and presence of PEA only, new infections do occur. Therefore, although there is scarce reference in the literature, PEA can have an important role in the FHB infectious process, explaining why the disease develops after anthesis.

In October 2011, during wheat anthesis, mean temperature of $20^{\circ} \mathrm{C}$ and 11 rain events were recorded. Head wetness coincided with the anther extrusion period, and the first FHB symptoms were observed on 10/26/2011, i.e., at 10 days after the last PEA assessment (Figure 2A, 2B).

Panisson et al. $(15,16)$ reported that, as the number of PEA increases with time until stabilizing, fungicide applications at the end of flowering may reach more PEA; therefore, more efficiently reaching the largest number of PEA. In China, a region where the highest FHB epidemics occur, two fungicide applications at anthesis, one early and another one at seven days later, are recommended (17), in order to protect the heads (FEA) for a longer period, compared with only one spray. They considered only FEA but not PEA.

The disease cycle initiates mainly with ascospores or asexual conidia. Ascospores are dispersed by the wind and conidia are splashed with the rain and deposited onto the anthers (4). During anthesis, the anthers naturally split to release pollen, which provides an entrance for the pathogen to the wheat flower. Anther extrusion also exposes the inner surface of the floral brackets, which can be directly penetrated (4). Low temperatures and adequate rainfall increase the frequency of open flowers $(9,22)$, while high temperatures and drought increase closed flowers (13). As indicated in the literature, flower opening is needed to extrude the anthers, which means that open flowers can be involved in floret infection by G. zeae.

Sage and Isturiz (22) found genotypic differences for the percentage of open florets, which were strongly associated with anther extrusion.

\section{Fungi isolated from partially exserted anthers}

In addition to $F$. graminearum, other fungi colonizing PEA were isolated: Fusarium sp., Alternaria sp. Drechslera sp., and Epicoccum sp. However, F. graminearum incidence significantly differed (Figure
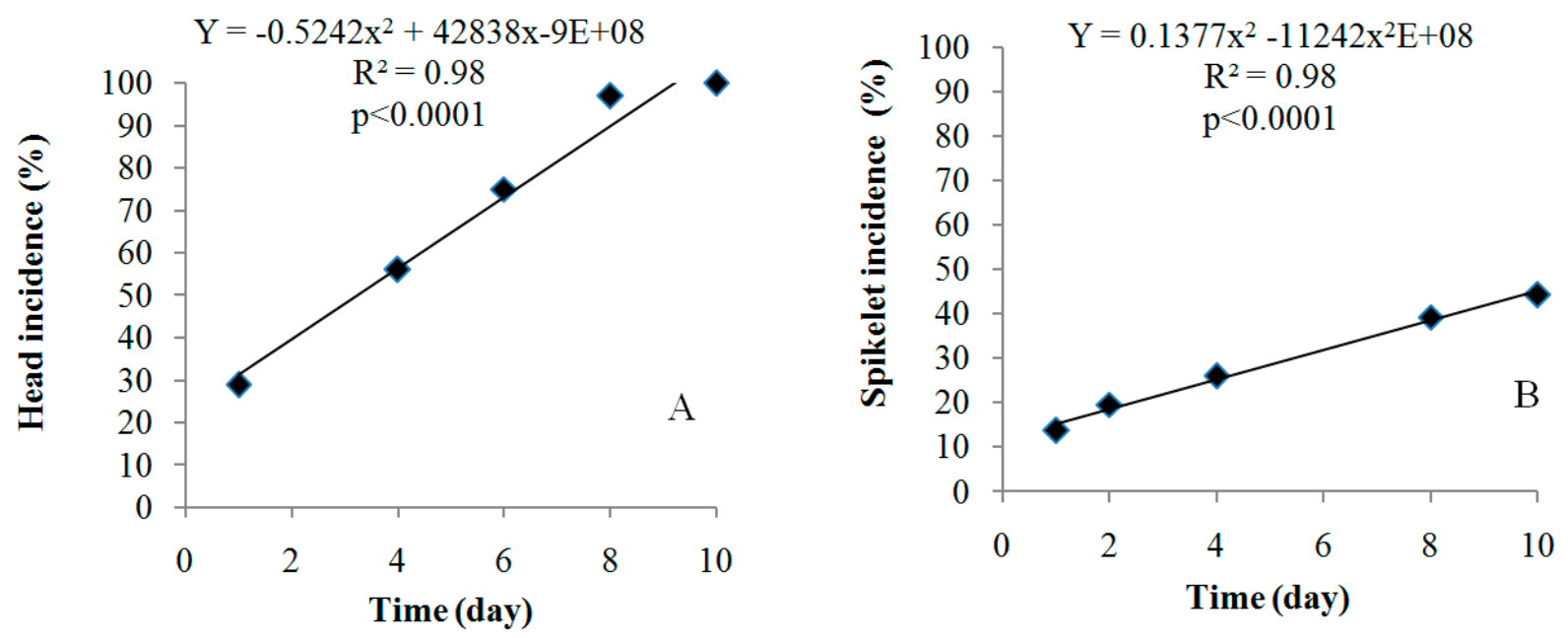

Figure 2. Disease progress lines of fusarium head blight: (A) head incidence (\%) and (B) spikelet incidence (\%), wheat cultivar Marfim.

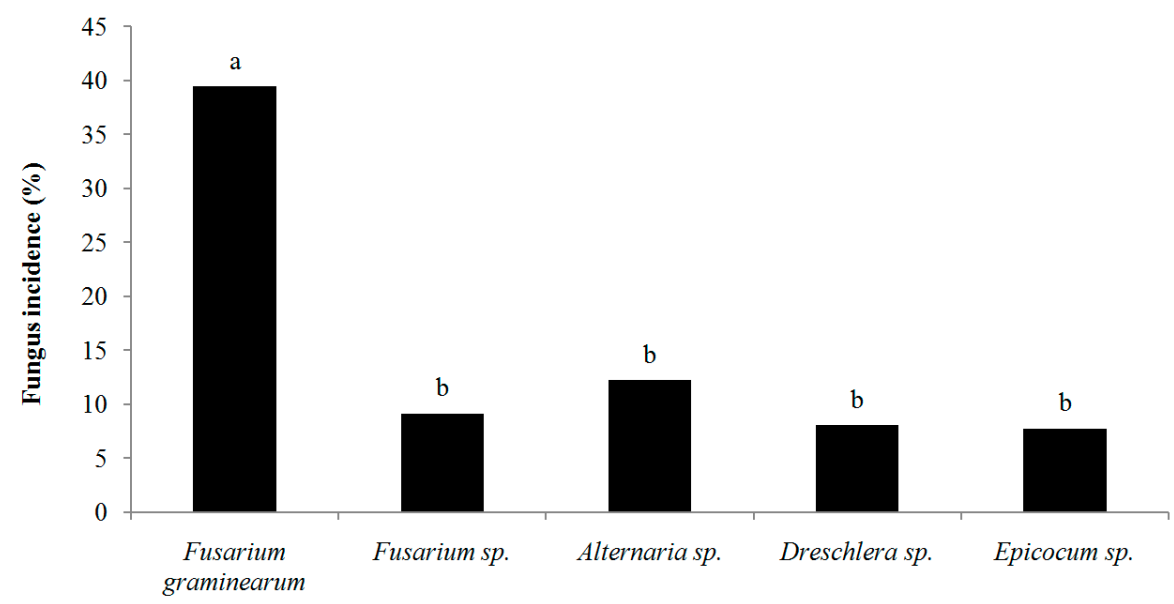

Figure 3. Incidence of fungi in partially exserted anthers of wheat. Means followed by the same letter on the columns do not differ according to Tukey's test at 0.01 . CV \% $=29.87$ (Anthers sampled from Oct. $7^{\text {th }}$ to Nov. $4^{\text {th }}, 2011$ ). 


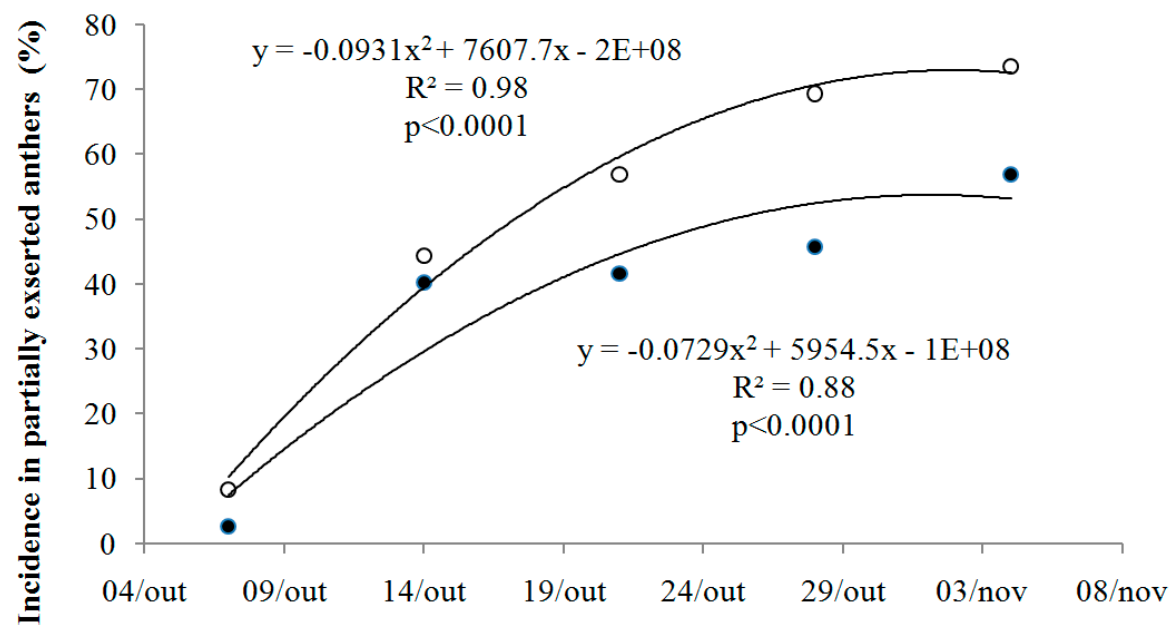

Time/date

- 1/4 PDA O Segalin \& Reis semi selective medium

Figure 4. Relationship between Fusarium graminearum incidence in partially exserted anthers and time after anthesis.

3), showing to be four-fold higher than that of other fungi, which did not differ among them. Panisson et al. (16) showed that the infection was twice as much in PEA than in FEA. Therefore, the isolated fungus population seems not to be antagonistic to $F$. graminearum. Those fungi did not compete for the infection sites of FHB in wheat, not interfering in the incidence, as shown in our study (Figure 4). Thus, the infection continuous to occur even after the presence of FEA.

\section{Role of fully exserted and partially exserted anthers in the infection \\ Both FEA and PEA were found on the same day, but PEA remained trapped in the ear for a longer time than FEA (Figure 2A). It is likely that those that remain exposed to the inoculum for a longer time are most important for the infection. The presence of PEA increased the predisposition period to the inoculum, and the final FHB incidence after anthesis depended on their presence. PEA infection by F. graminearum}

increased from Oct 4th to Nov 8th (34 days). On Oct 14th, FEA were not present due to their dehiscence and only PEA remained. Therefore, the only infection sites present after Oct 14th were PEA. FHB intensity has increased over time in the absence of FEA, showing the importance of PEA to the infectious process (Figure 4).

Fusarium head blight - a mono- or polycyclic disease?

The repeated infections which increased head incidence (Figure 5A) suggested that FHB could have secondary cycles, and this was shown when data were subjected to epidemiological models and the obtained disease progress curve was S-shaped or sigmoid, a characteristic of polycyclic diseases (Figure 5B). Polycyclic pathogens complete more than one cycle per host, continuously producing reproductive structures during the host presence, generating multiple disease cycles in the same plant.

It should be considered that G. zeae primary inoculum is always
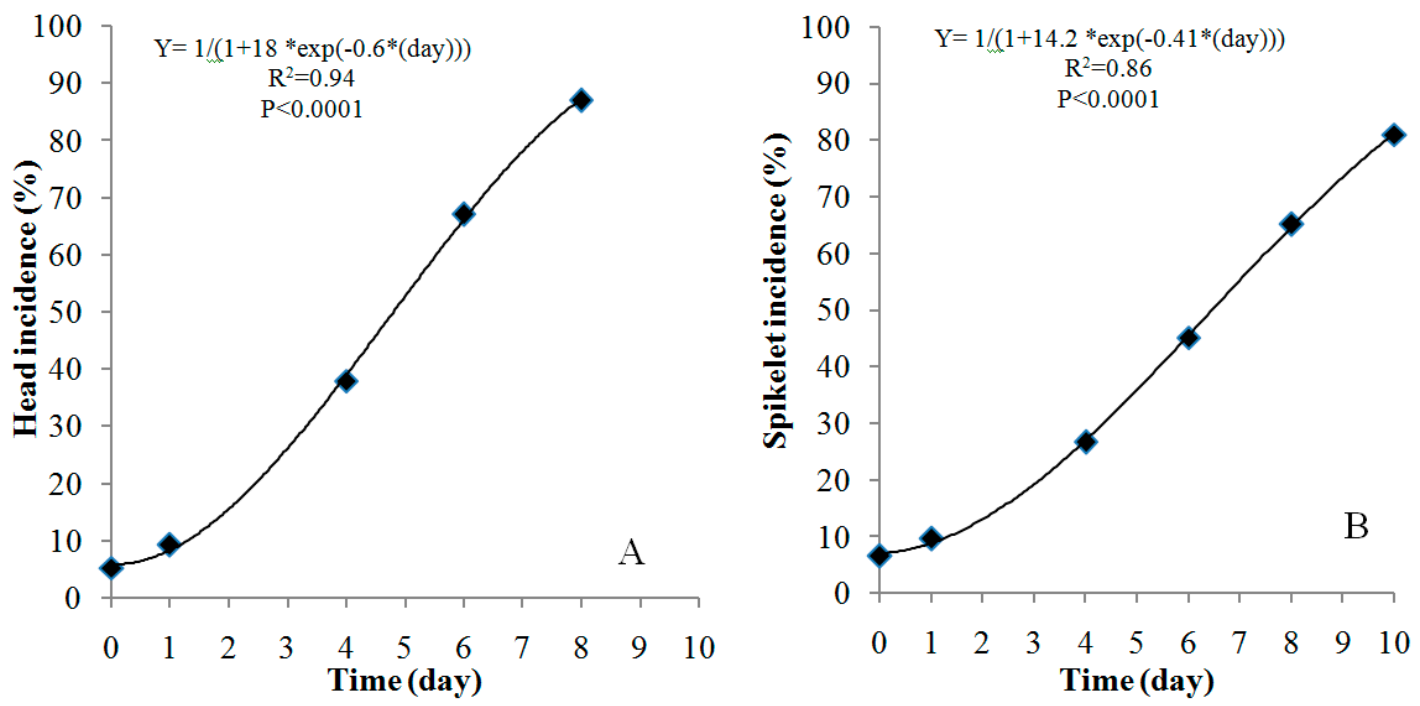

Figure 5. Disease progress curves of fusarium head blight: (A) head incidence (\%) and (B) spikelet incidence (\%), wheat cultivar Marfim (Assessment period from Oct. $26^{\text {th }}$ to Nov. $4^{\text {th }}, 2011$ ). 
present as ascospore in the air throughout the year $(18,19)$. Thus, new spikelet infection only depends on the wetting period to succeed to spore penetration and start the colonization. The major sources of inoculum in Brazil are perithecia, which are saprophytically formed on different small grain residues and on senesced/killed tissues of several Gramineae such as weeds, wild plants and pasture $(19,20)$. It is likely that macroconidia produced in the first infected spikelets are not the most important secondary inoculum. In the presence of PEA, over unlimited time, new infections could occur via PEA after anthesis with the same primary inoculum out of the host plant (perithecia in crop residue on the ground). This fact resulted in FHB growth due to the new infections, not caused by the secondary inoculum produced on the first infected spikelets. Depending only on the primary inoculum, G. zeae infections can occur since the first exserted anthesis, with the presence of FEA only (seven-day duration), up to the grain dough stage, when only PEA is present.

\section{Gibberella zeae penetration - via anthers or glume opening?}

Some authors have argued that $G$. zeae can enter the floret by the glume opening at the time of anther exclusion. During anthesis, the anthers naturally split to release pollen, which provides an entrance for the pathogen to the floret. Also during anthesis, florets of wheat head remain open for only 12 to 20 minutes (9). Extrusion also exposes the poorly defended inner surface of the floral brackets, which can be directly penetrated (22). This can also be a penetration site; however, the occurrence of new infections after the absence of FEA and the presence of PEA alone indicate that this is not the only penetration mechanism.

Fusarium head blight chemical management. Taking into account the findings in the present paper and based on Reis \& Carmona (20) and Casa (7), we consider:

(i) Predisposition period to fusarium head blight infection. It extends from the beginning of flowering (presence of FEA and PEA) to the dough grain stage (presence of PEA only), i.e., Zadoks (30) stage 60-75. During this period, the heads (PEA) should be protected by fungicides;

(ii) Timing the first fungicide application. Fungicides should only be applied when the weather is favorable to infection during the predisposition period. Accordingly, the application must be performed before rain events. When it rains, the fungicide must have already been applied and the ears (PEA) must be protected. Failing rain does not justify the application because there is no infection.

(iii) The rain forecast reports made by CPTE / INPE (precision accuracy $>95 \%$ ) covering the following 24-72 hours.

(vii) Second application. An ear protection period of 15 - 20 days is considered. Therefore, if rain is forecasted for the 15 - 20 days after the first application, conduct reapplication.

Leaf diseases (leaf rust, leaf blights and powdery mildew) should be controlled according to the indications of the research institutes. Therefore, FHB control is independent of leaf disease management.

\section{REFERENCES}

1. Andersen, A.L. The development of Gibberella zeae head blight of wheat. Phytopathology, St. Paul, v.38, p. 595-611, 1948.

2. Arthur, J.C. Wheat scab. Bulletin of the Agricultural Experiment Statation of Indianaa/ Purdue University, Lafayettee, v.2, n.36, p. 129-132, 1891.

3. Atanasoff, D. Fusarium-blight (scab) of wheat and other cereals. Journal of Agricultural Research, 20:1-4, 1920.

4. Brown, N.A., Bass, C,; Baldwin, T.K.; Chen, H; Massot, F.; Carion, P.W.; Urban. M. van de Meene, A.M.; Hammond-Kosack, K.E. Characterisa- tion of the Fusarium graminearum wheat floral interaction. Journal of Pathogens, Article ID 626345, 9 pages doi:10.4061/2011/626345, 2011.

5. Brustolin, R; Zoldan, S. M.; Reis, E. M.; Zanatta, T.; Carmona, M. Weather requirements and rain forecast to time fungicide application for Fusarium head blight control in wheat. Summa Phytopathologica, Botucatu, v.39, n.4, p.248-251, 2013.

6. Casa, R.T.; Reis, E.M.; Blum, M.M.C.; Bogo, A.; Scheer, O.; Zanata, T. Damage caused by infection with Gibberella zeae in wheat. Fitopatologia Brasileira, Brasília, DF, 29: 289-293. 2004.

7. Casa, R.T.; Bogo, A.; Moreira. E.N.; Kuhnem Júnior. Application time and fungicide performance to control wheat scab. Ciência Rural, Santa Maria, v. 37. P.1558-1563, 2007.

8. Costa Neto, J.P. Parasitas de plantas cultivadas no Rio Grande do Sul. Porto Alegre, Secretaria de Estado dos Negócios da Agricultura, Indústria e Comércio. 21p. 1947

9. De Vries, A.P.H. Flowering biology of wheat, particularly in view of hybrid seed production - A review. Euphytica, Wageningen, v.20, p. 152 - 170, 1971.

10. Engle, J.S.; Lipps, P.E.; Grahan, T.L.; Boehm, M.J. Effects of choline, betaine, and wheat floral extracts on growth of Fusarium graminearum. Plant Disease, St. Paul, v. 88, p. 175-180, 2004.

11. Kuhnem Junior, P.R.; Casa, R.T.; Moreira, E.N.; Rizzi, F.P.; Bogo, A. Desempenho de fungicidas no controle de doenças foliares em trigo. Revista de Ciências Agroveterinárias, Lages, v. 8, p. 35-42, 2009.

12. Khonga, E.B.; Sutton, J.C. Inoculum production and survival of Gibberella zeae in maize and wheat residues. Canadian Journal of Plant Pathology, v.10, p. 232-239, 1988.

13. Obermayer, E. Untersuchung über das Blühen und die Befruchtung von Winterroggen und Winterweizen. Zeitschrift Pflanzenzücht, Berlin. v.4, p.347-403, 1916.

14. McKay, R.: Loughnane, J.B. Observations on Gibberella saubinetii (Mont.) Sacc. on cereals in Ireland in 1943 and 1944.Scientific Proceedings of the Royal Dublin Society. Dublin, v.24, n.2, p, 9-18, 1945.

15. Panisson. E.; Reis, E.M.; Boller, W. Efeito da época, do número de aplicações e de doses de fungicida no controle de giberela em trigo. Fitopatologia Brasileira, Brasília, DF, v. 27 (5), 495-499, 2002 (English abstract).

16. Panisson E, Reis EM, Boller W. (2003) Quantification of damage caused by scab in winter cereals in 2000 growing season in Passo Fundo, RS. Fitopatologia Brasileira, Brasília, DF, 28:189-192.

17. Parry DW, Jenkinson P, McLeod L (1995) Fusarium ear blight (scab) in small grain cereals - a review. Plant Pathology, London, v.44, p. 07-238, 1995.

18. Reis, E.M (1988) Quantificação de propágulos de Gibberella zeae no ar através de armadilhas de esporos. Fitopatologia Brasileira, Brasíla, DF, v. 13, n. 324-327, 1988 (English abstract).

19. Reis, E.M. Perithecial formation of Gibberella zeae on senescent stems of grasses under natural conditions. Fitopatologia Brasileira, Brasília, DF, v.15, n.52-54, 1990.

20. REIS, E.M.; CARMONA, M. Integrated disease management of Fusarium head blight. In: Magliano, T.M.A.; Chulze, S.N. Fusarium head blight in Latin America, Dordrecht, Springer Science, 2013. 159-173 p.

21. Reis, E.M.; Blum, M.M.C.; Casa, R.T.; Medeiros, C.A. Grain losses caused by the infection of wheat heads by Gibberella zeae in southern Brazil, from 1984 to 1994. Summa Phytopathologica, Botucatu, 22:134-137, 1996.

22. Sage GCM, Isturiz MJD (1974) Inheritance of anther extrusion in two spring wheat varieties. Theoretical Applied Genetics.45:126-133.

23. Segalin. M.; Reis E.M. Semi-selective medium for Fusarium graminearum detection in seed samples. Summa Phytopathologia, Botucatu, vol.36, n.4, pp. 338-341, 2010.

24. Strausbaugh, C.A.; Maloy, O.C. Fusarium scab of irrigated wheat in central Washigton. Plant Disease, St. Paul, v.70, p. 1104-1106, 1986.

25. Strange, R.N.; Smith, H. A fungal growth stimulant in anthers which predisposes wheat to attack by Fusarium graminearum. Physiological Plant Pathology, St. Paul, v. 1, p. 141-150, 1971.

26. Strange, R.N.; Majer, J.R.;, Smith, H. (1974) The isolation and identification of choline and betaine as two major components in anthers and wheat germ that stimulate Fusarium graminearum in vitro. Physiological Plant Pathology, ST. Paul, 4:277-290, 1974.

27. Sutton, J.C. (1982) Epidemiology of wheat head blight and maize era rot caused by Fusarium graminearum. Canadian Journal of Plant Pathology, London, v.4, n.2, p. 195-209, 1982.

28. Wiese, M.V. Compendium of wheat diseases. 2ed. St. Paul: American 
Phytopathological Society. 106p. 1987.

29. Vargas, P.R. Previsão de epidemia de giberela através da modelagem da antese do trigo. Dissertação (Mestrado em Agronomia). Passo Fundo. Universidade de Passo Fundo, (English abstract). 1988.

30. Zadoks, J.C., Chang, T.T. \& Konzak, C.F. A decimal code for the growth stages of cereals. Weed Research, Oxford, v.14:415-421, 1974

31. Zoldan, S.M. Risk areas, anthesis characterization in winter small grains and warning system for head blight in wheat. Thesis (Doutorate in Agronomy) - Faculdade de Agronomia e Medicina veterinária, Universidade de Passo Fundo. Passo Fundo, RS. 152 p. (English abstract).2008. 